Original paper

\title{
Problems and challenges in detection of pre-Mesozoic maar volcanoes: example from the Principálek Volcano in the Permian Krkonoše Piedmont Basin
}

\author{
Jan VALENTA ${ }^{1 *}$, Vladislav RAPPRICH², Marcela STÁRKOVÁ ${ }^{2}$ Zuzana SKÁCELOVÁ2, Lucia \\ FOJTÍKOVÁ ${ }^{1}$, František STANĚK' ${ }^{1}$, Jan BALEK ${ }^{1}$ \\ ${ }^{1}$ Institute of Rock Structure and Mechanics, Academy of Sciences of the Czech Republic, V Holešovičkách 41, 18200 Prague 8, Czech \\ Republic; valenta@irsm.cas.cz \\ ${ }^{2}$ Czech Geological Survey, Klárov 3, 11821 Prague 1, Czech Republic \\ * Corresponding author
}

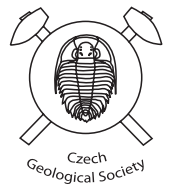

\begin{abstract}
The Permian pyroclastic deposits on the Principálek Hill SW of Vrchlabí (Czech Republic) were investigated by means of geological mapping and geophysics. The pyroclastic rocks are exposed in several small coherent outcrops, yet many interpretations are based on debris. The preserved textures enable reconstruction of eruptive styles. The volcanism started with phreatomagmatic eruptions documented by the fine-grained tuff with accretionary lapilli at the base. Subsequently, the activity changed to phreato-Strombolian/Surtseyan producing lapilli-tuffs and lapillistones. These events were followed by a Strombolian phase as evidenced by ill-sorted scoriaceous tuff-breccias with volcanic bombs. The uppermost unit consists of welded lava agglutinates and basaltic lavas suggesting a Hawaiian style of eruption. One of the basaltic feeder necks is exposed in a small abandoned quarry.

Geophysical surveys were carried out over the extent of pyroclastic deposits. These included gravimetry, magnetometry, and DC resistivity tomography. The magnetic data indicate the occurrence of basaltic dykes in the central part of the pyroclastic deposits. The DC tomography confirms the presence of dykes, enables estimation of the pyroclastic deposits thickness, and provides evidence for the size and position of the maar-diatreme. Gravity data yield an insignificant low associated with the diatreme, which is likely a product of low rock-density contrast between the diatreme and country rocks. We argue that this is due to short time gap between sedimentation and volcanic activity and also related to conjoint burial and diagenetic history of the diatreme and the surrounding country rocks.
\end{abstract}

Keywords: diatreme, geophysics, volcanology, Permian, Krkonoše Piedmont Basin, scoria cone

Received: 25 June 2013; accepted: 23 May 2014; handling editor: V. Babuška

\section{Introduction}

There are significantly fewer research articles on geophysical detection of Pre-Mesozoic volcanoes than those dealing with Tertiary and Quaternary ones, except surveys focused on detection of economically important kimberlite pipes (e.g., Macnae 1995; Sarma et al. 1999; Vasanthi and Mallick 2001; Cunion 2009; Kjarsgaard et al. 2009; Pettit 2009; La Terra and Menezes 2012). The often poor exposure and frequent post-emplacement alteration are among the most likely reasons for this situation.

Recently, the internal architecture and emplacement processes of Late Carboniferous to Early Permian basaltic diatremes into an extensive rift system in the northern Variscan foreland in the East Fife (Scotland) area was studied by Gernon et al. (2013). However, the architecture of these diatremes was based only on the field geological evidence without investigating the geophysical signature reflecting the inner structure of the diatremes.
Evidence of phreatomagmatic explosions were also found by Lorenz (1971) in the Permian of the SaarNahe Basin (Germany) and by Stárková et al. (2011) in the Levín volcanic field in the Krkonoše Piedmont Basin (Czech Republic). However, the authors did not attempt to visualise the subsurface volcanic structures, either.

The research and imaging of Tertiary and Quaternary maar volcanoes is often successfully carried out using various geophysical methods, mainly gravimetry and magnetics and, to a lesser extent, geoelectrical and seismic methods (e.g., Cassidy et al. 2007; Mrlina et al. 2009; Matthes et al. 2010; Skácelová et al. 2010; Gebhardt et al. 2011; Bolós et al. 2012; Schmidt et al. 2013). The gravimetry mostly relies on a density contrast between the diatreme and a country rock, as the material within the diatreme ("fluffed up" during eruption) has lower bulk density than the surrounding rocks. The magnetic method is capable of mapping rocks with contrasting magnetic susceptibility - e.g. 


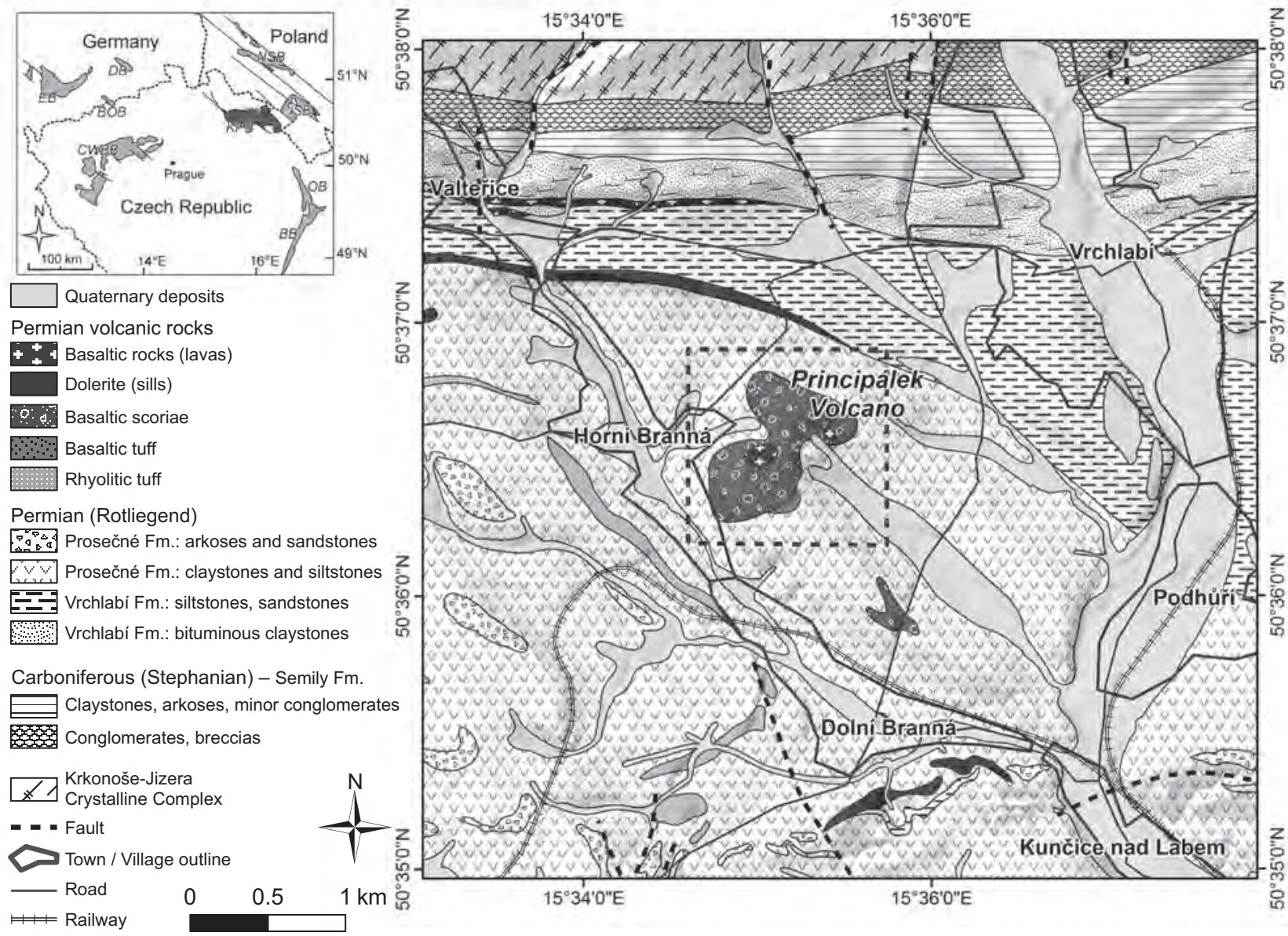

Fig. 1 Geological map of the Principálek Volcano and its surroundings. The inset shows position of the area within the Late Palaeozoic intermontane basins in the Bohemian Massif and its northern vicinity. BB - Boskovice Basin, BOB - Brandov-Obersdorf Basin, CWBB - Central-Western Bohemia Basin, DB - Döhlen Basin, EB - Erzgebirge Basin, ISB - Intra-Sudetic Basin, KPB - Krkonoše Piedmont Basin, NSB - North-Sudetic Basin, OB - Orlice Basin (adapted after Pešek 2001). Location of Fig. 2 is indicated by the quadrangle.

dykes and flows of basic lavas. The geoelectrical and seismic methods are usually slower to be carried out in the field and their imaging depth, in most cases, does not enable mapping of the whole volcanic structure. On the other hand, they offer more detailed and precise images of the subsurface.

\section{Geological setting}

Permian maar-diatreme volcano (named after the spot height Principálek SW of Vrchlabí - Figs 1-2) occurs in the northern part of the Late Paleozoic Krkonoše Piedmont Basin with volcano-sedimentary infill (Pešek 2001). The morphologically noticeable volcano is situated in the northern vicinity of the Lower Rotliegend; it forms a part of the so-called Levín Volcanic Field (Stárková et al. 2011). The Levín Volcanic Field consists of monogenetic basaltic volcanism products - phreatoStrombolian, Strombolian, and Hawaiian pyroclastic deposits and lava flows as well as pillow lavas. The rocks of the volcanic structure studied for this contribution are of the same basaltic character and, together with the other subvolcanic equivalents (sills, dykes), intruded sediments of the surrounding Lower Rotliegend (fluvial and lacustrine claystones, siltstones and fine-grained sandstones of the Prosečné Fm.). Apart from the Prosečné Fm. (with a thickness of c. 200-300 m), the majority of the feeder systems intruded the underlying Rotliegend - the Vrchlabí Fm. (up to $530 \mathrm{~m}$ thick) and the older Westphalian-Stephanian Semily Fm. (450 m). The total thickness of the sediments could be nearly $1300 \mathrm{~m}$. According to Awdankiewicz (1999) and Ulrych et al. (2002), the igneous activity could have been related to extensional post-orogenic processes in the Central Variscides. Geissler et al. (2012) suggested, based on a teleseismic receiver-function study, a possibility of an orogenic delamination of the continental lithosphere leading to production of asthenospheric mantle-derived melts (e.g., Awdankiewicz 2007). 


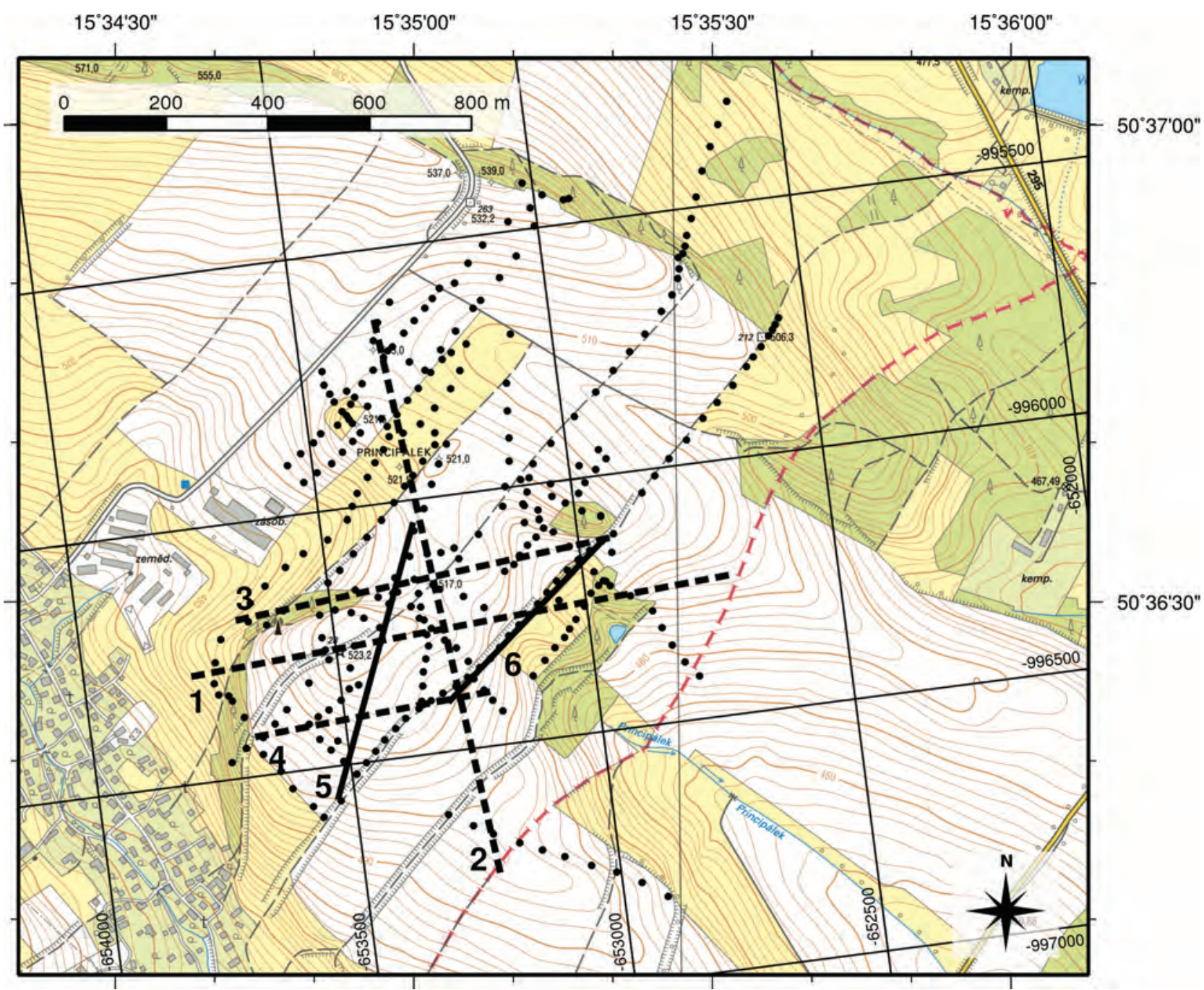

Fig. 2 Detailed topographical map of the Principálek Hill and positions of individual measurements. The gravity profiles (1-4) are plotted with broken lines, DC tomography profiles (5-6) with solid lines and individual magnetic measurements as points. The map contains an additional grid of local Cartesian coordinates - the S-JTSK grid widely used in the Czech Republic utilized for mapping geophysical data in this study.

\section{Methods}

\subsection{Geological mapping}

The locality was discovered during the $1: 10000$ geological mapping for a geological map on the scale $1: 25000$ (Prouza et al., 2012) when indications of pyroclastic deposits with associated small occurrences of coherent volcanic rocks were found. The variety of observed pyroclastic rocks with associated remnants of lava flows suggested a complex eruptive history ranging from a maar-volcano phreato-magmatic eruption to Hawaiian style eruption. The aerial extent of individual types of pyroclastic rocks was determined by a field mapping based on several small outcrops and debris in tilled fields. The subsequent rock sampling and detailed optical petrography studies were carried out at the Czech Geological Survey.

\subsection{Geophysical methods}

The geological indications of possible presence of the maar volcanism needed further verification by finding the source diatreme. As geophysical methods are often successfully used for young volcanoes, we have also utilized them within the research of a possible Permian diatreme.

\subsubsection{Gravimetry}

The gravity was measured using the Scintrex CG-5 relative gravity meter on four profiles $1-4$ (Fig. 2) with the step between measuring points of $30 \mathrm{~m}$. The base station was situated roughly in the centre of the area and was reoccupied every $2-3 \mathrm{~h}$ to correct the measured data for an instrument drift. 


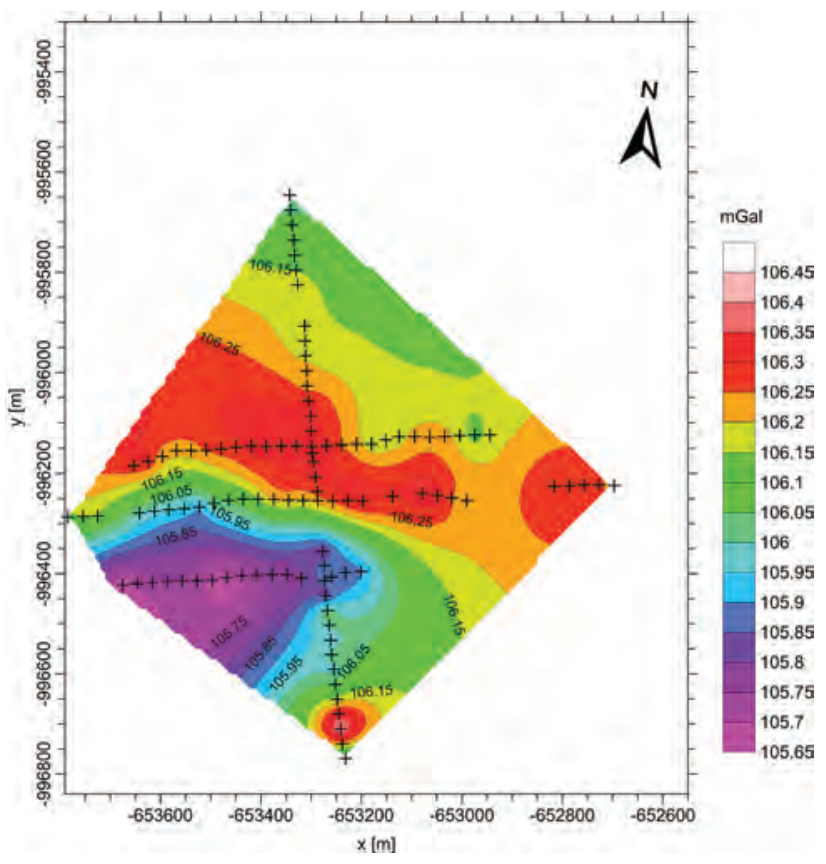

Fig. 3 Map of the Bouguer anomalies. Please note the very low range of the gravity readings $(0.8 \mathrm{mGal})$. The crosses depict individual gravity points.

The gravity on individual stations was averaged for $60 \mathrm{~s}$. Two or three of these readings were then averaged to form a gravity datum for each station. In case of unfavourable measuring conditions (wind, unstable ground), the number of individual gravity readings was incerased and, before averaging, outliers were removed. In total, 111 gravity points were measured with the median error, based on repeated measurements, of $0.015 \mathrm{mGal}$. Heights were surveyed using the Leica TC1010 total station with accuracy of $5 \mathrm{~cm}$.

The measured gravity data were first of all corrected for the instrument drift based on the repeated readings on the base station. The Bouguer anomalies were then calculated (Fig. 3), the density used for the Bouguer slab being $2.45 \mathrm{~g} / \mathrm{cm}^{3}$. This density was derived following Nettleton (1939) and corresponds to densities of rock samples (Tab. 1) and also to densities reported for the Permo-Carboniferous sediments throughout the
Bohemian Massif (Ibrmajer and Suk 1989). The overall accuracy of the Bouguer anomalies was $0.025 \mathrm{mGal}$.

\subsubsection{Magnetometry}

The ground magnetic survey was carried out on two parallel profiles running through the centre of the investigated area and on several additional short profiles (Fig. 2). The magnetic data were acquired using the portable proton magnetometer PGM-1 (SatisGeo, Ltd.) and were corrected for daily variations by repeated measurements on the base station. However, amplitudes of these variations were much lower than those of the registered magnetic anomaly. The measured magnetic field is shown in Fig. 4.

\subsubsection{Resistivity tomography}

The DC (Direct Current) resistivity tomography (also known as the ERT - electrical resistivity tomography) was measured on two profiles situated according to the results of potential methods (profiles 5 and 6 in Fig. 2). The data were obtained using the ARES resistivity system (GF Instruments, Ltd.) and electrode spacing along the profile was $5 \mathrm{~m}$. The resistivity data were processed using the $2 \mathrm{D}$ inversion code Res2dInv by M. H. Loke (Loke and Barker 1996) during five iterations. Final RMS (Root Mean Square) error was relatively low $-7.0 \%$ for profile 5 (Fig. 5) and $2.0 \%$ for profile 6 (Fig. 6).

\section{Results}

\subsection{Geological characteristics}

Sequence of volcanic rocks cropping out in the SW vicinity of Vrchlabí (surroundings of the Principálek spot height) is morphologically conspicuous. Various types of pyroclastic rocks can be found on the surface, where they mostly cover coherent volcanic rocks. The base of the pyroclastic sequence consists of fine-grained tuff (Fig. 7a) with abundant accretionary lapilli (Fig. 7b; core-type predominating over rim-type accretionary lapilli) and their fragments up to $1 \mathrm{~cm}$ across. The fine-grained tuff crops out at the SE and E margins of the study area with an inferred maximum thickness of a few metres. Intense fragmentation combined with limited spatial extent suggests that 


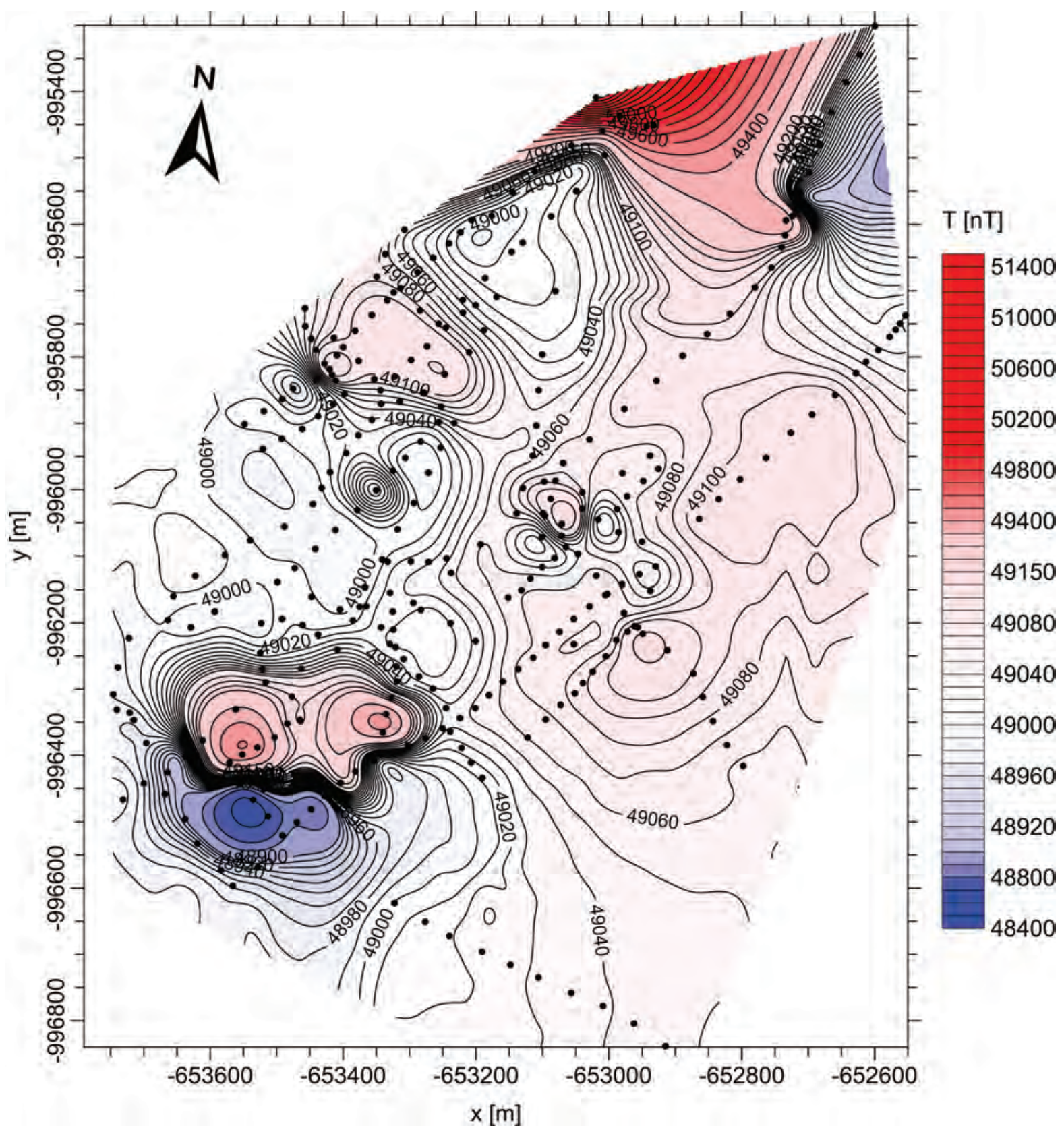

Fig. 4 Map of the total vector of the magnetic field. The points denote individual magnetic readings.

phreato-magmatic eruptions produced the fine-grained tuff. Locally, low-angle diagonal bedding can also be observed, which we interpret as an evidence of surge deposition accompanying the fall deposits.

The grain-size of tuff increases upwards forming transitions from lapilli-tuff to lapilli-stone. The lapilli-tuff is poorly sorted, matrix supported, and contains fragments of scoria as well as fragments of accretionary lapilli (Fig. 7c). Most of the juvenile fragments are hypocrystalline (palagonitized with phenocrysts of plagioclase up to $3 \mathrm{~mm}$ ) and poorly vesiculated with scarce or no cuspate rims (Fig. 7d) suggesting hydroclastic fragmentation and phreato-Strombolian or Surtseyan style of eruption. Therefore, we interpret these deposits as a transition to overlying planar-bedded poorly sorted scoriaceous lapilli-stone to tuff-breccia (Fig. 7e-g). The thickness of this unit does not exceed $50 \mathrm{~m}$. The bedding dips some $10-15^{\circ}$ to $\mathrm{S}-\mathrm{SE}$, conformably with the surrounding sedimentary sequences. Coarse-grained matrix encloses macroscopically apparent fragments of altered scoria $(0.5 \mathrm{~cm}$ up to a few $\mathrm{cm}$ ) and abundant spindle-shaped bombs consisting of fine-grained aphanitic, slightly vesicular mafic lava. The size of bombs reaches $30 \mathrm{~cm}$. Many ash aggregates, cuspate glass shards, palagonite frag- 


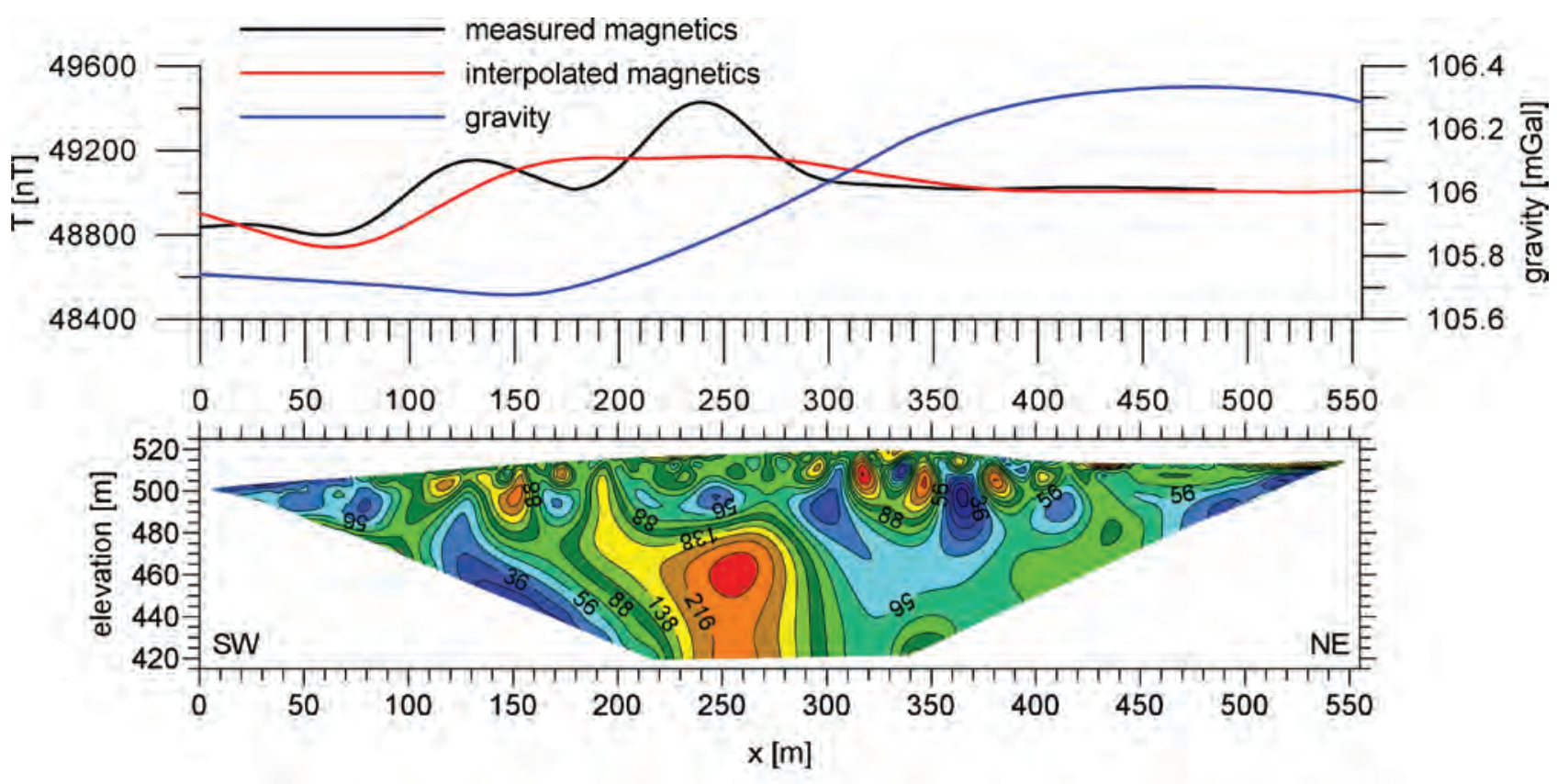

Resistivity $[\Omega \mathrm{m}]$

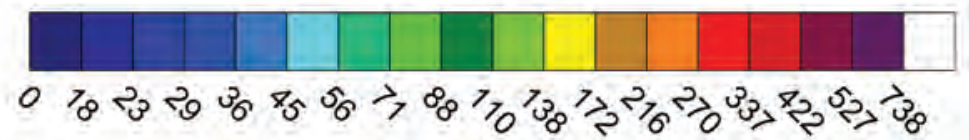

Fig. 5 The resistivity tomography section measured along profile 5 plotted together with gravity and magnetic data. The gravity data are taken from the gridded gravity field (Fig. 3). The first set, the measured magnetics, contains data measured directly along a curved profile close to profile 5 . The second one, the interpolated magnetics, is taken from the gridded magnetic field (Fig. 4) along the course of profile 5.

ments, scarce isolated phenocrysts (mica and feldspar) and quartz xenocrysts can be observed microscopically in groundmass. Finer layers are dominated by matrix consisting of variable amounts of quartz, feldspar, ash aggregates and deformed accretionary lapilli, rarely also mica flakes and small lithic clasts (red claystones and

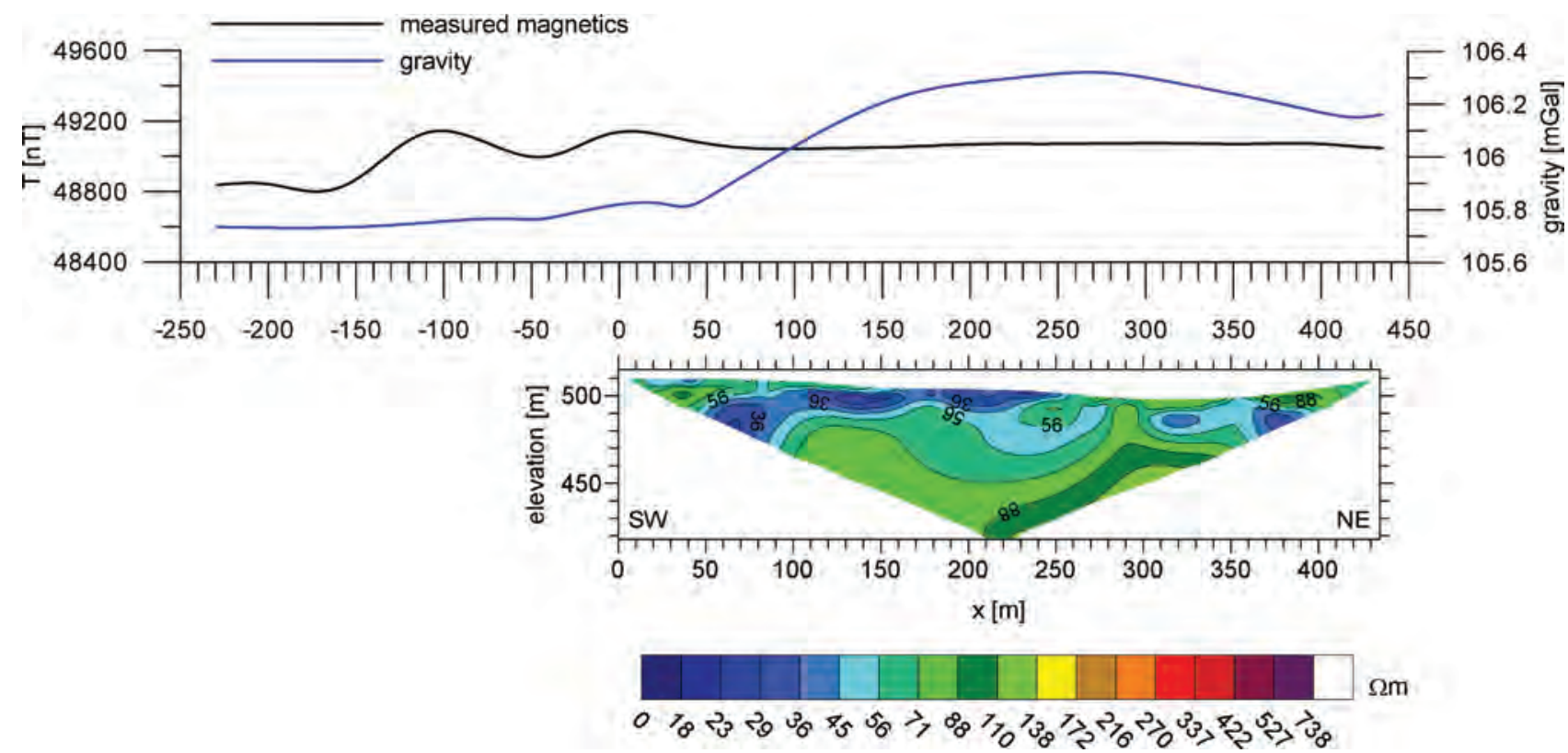

Fig. 6 The resistivity tomography section along profile 6. The gravity data are taken from the gridded Bouguer gravity field (Fig. 3). The magnetic data were directly measured along this profile. 

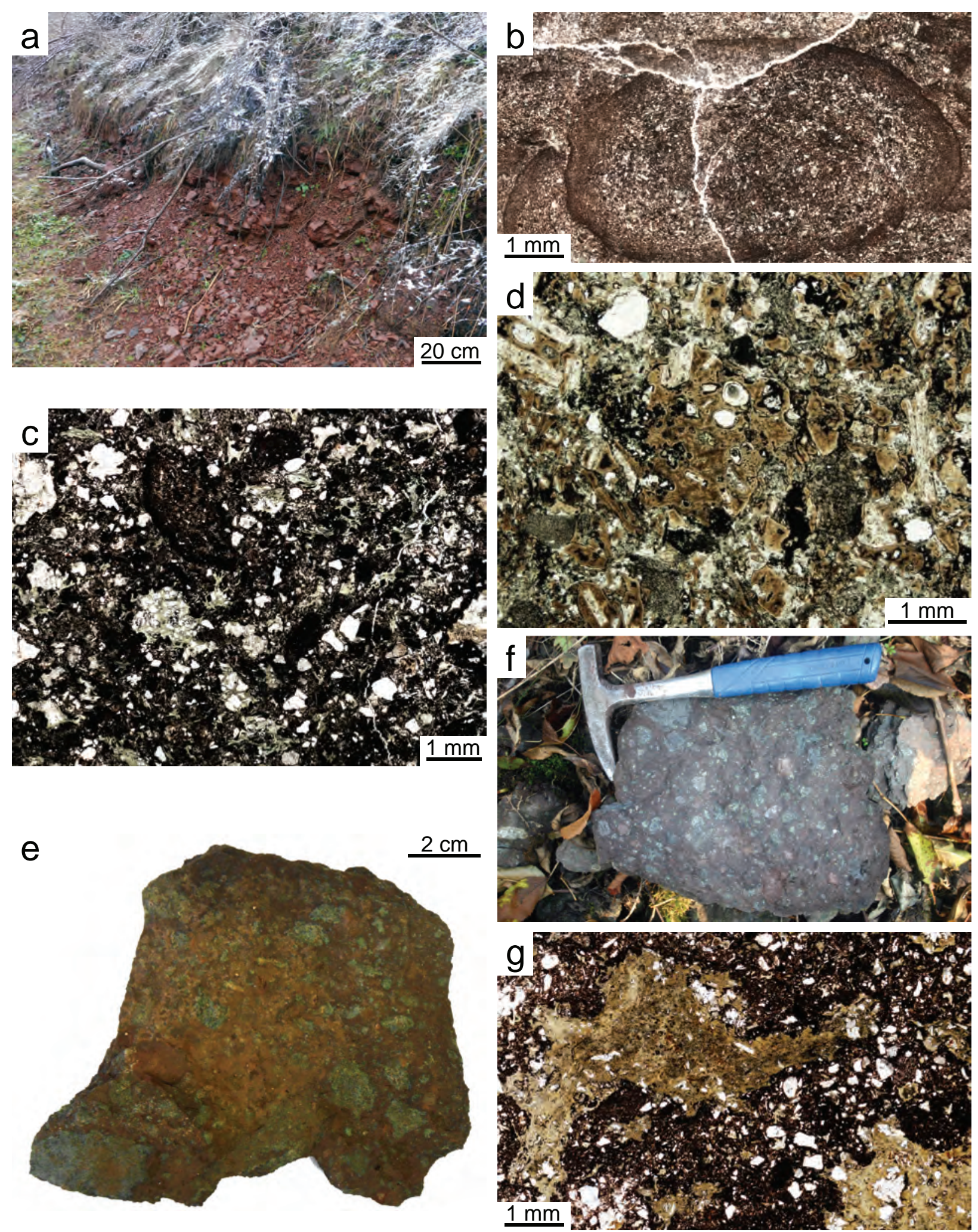

Fig. 7 Pyroclastic rocks of the Principálek Volcano: a - Outcrop of the fine-grained phreato-magmatic tuff on the eastern margin of Principálek Hill; b - Photomicrograph of core type accretionary lapilli surrounded by fragments of other accretionary lapilli in the fine-grained phreatomagmatic tuff (plane-polarized light, PPL); c - lapilli tuff containing abundant fragments of scoria and of accretionary lapilli (PPL); d - lapilli tuff containing poorly vesiculated fragments of hypocrystalline basaltic lava with plagioclase laths (PPL); e-f - blocks of scoriaceous lapilli tuff to lapilli breccia with chloritized (green) fragments of scoria, samples from the SW part of the hill (geological hammer is $30 \mathrm{~cm}$ long); $\mathbf{g}-\mathrm{irregular}$ densely vesiculated scoria fragment in scoriaceous lapilli breccia (PPL). 

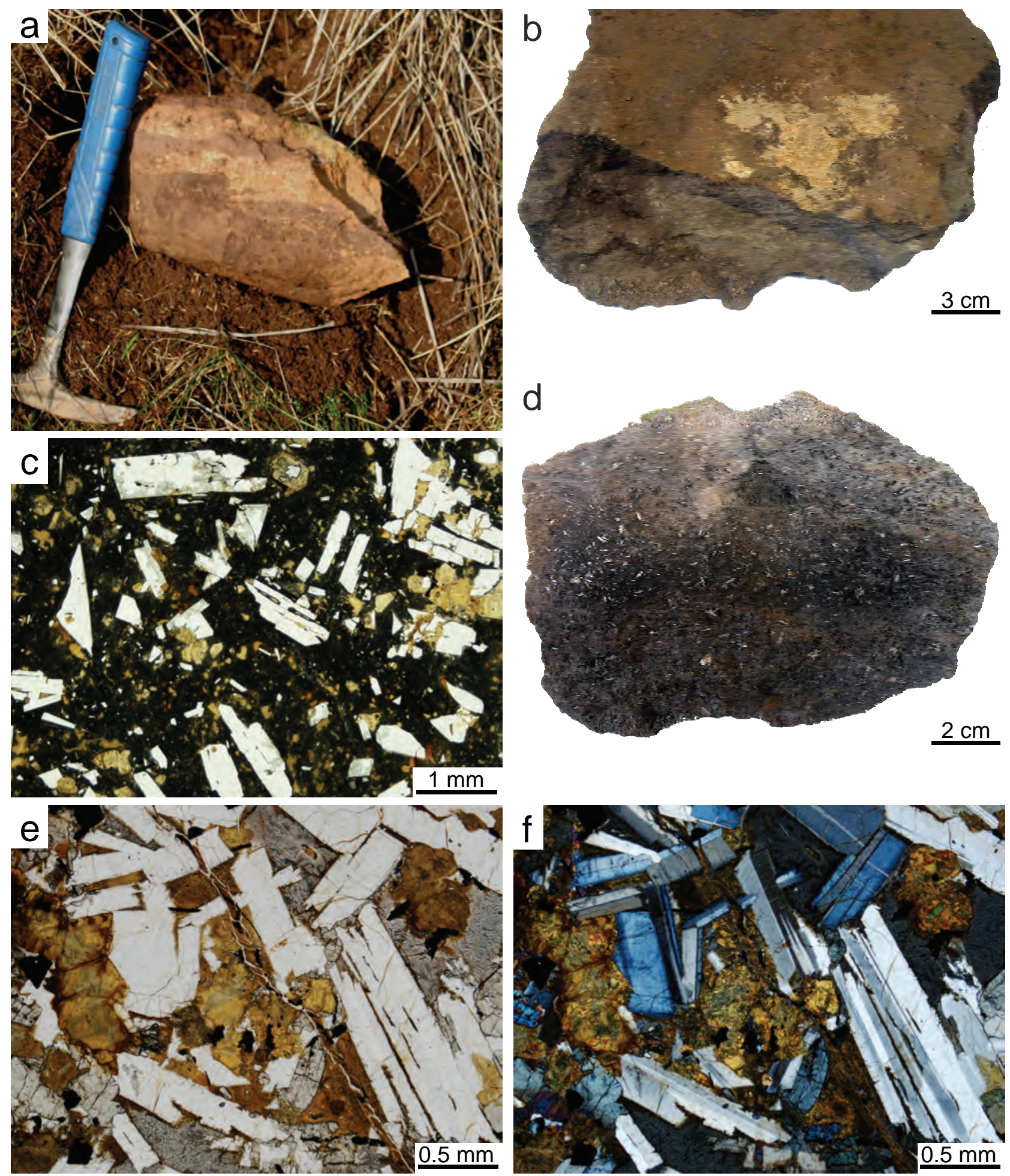

Fig. 8 Lavas and intrusive rocks of the Principálek Volcano: a-b - Blocks of welded lava agglutinate from the apical plateau of Principálek Hill; c - Basalt from the feeder neck exposed in the north-eastern part of Principálek Hill (PPL); d - Block of densely vesiculated basaltic lava from the apical plateau of Principálek Hill (scale-bar in $\mathrm{cm}$ ); e-f - Photomicrograph of the dolerite from the sill exposed $500 \mathrm{~m}$ north of Principálek Hill (plane- and cross-polarized light, respectively)

siltstones). The size of scoria fragments and also their frequency increases upwards. The scoria fragments are altered (chloritized) with plagioclase laths up to $0.5 \mathrm{~mm}$ long. The matrix contains abundant altered glass-shards and fragments of plagioclase crystals. Quartz xenocrysts occur rarely. 
The entire sequence is capped by lava agglutinates (Fig. 8a-b) with a transition to fine-grained slightly porphyric olivine basalt to basaltic andesite lava (Fig. 8c-d). The lava agglutinates consist of welded lava shreds turning red through oxidation of scoria and highly vesiculated lava. Such deposits are characteristic of Hawaiian style eruptions of gas-poor magmas. Coherent basalts are also associated with a feeder neck exposed in the northeastern part of the locality.

There is a microgabbro sill (Fig. 8e-f) exposed some $500 \mathrm{~m}$ north of Principálek extending to the west. The medium- to coarse-grained microgabbro sill has an interstitial texture. The rock consists of plagioclase laths (up to $4 \mathrm{~mm}$ long), altered olivine, minor pyroxene, magnetite, and relatively abundant ilmenite. The sill is $30 \mathrm{~m}$ thick and inclined southwards. Although the textures (medium-grained interstitial and fine-grained porphyritic respectively) of microgabbro in the northern vicinity and lavas within the Principálek Volcano differ, their mineral composition (Prouza et al. 2012) suggests that these rocks might be of the same source. Therefore, we argue that the microgabbro sill could be associated with the feeder system of the Principálek Volcano.

\subsection{Results of geophysical methods}

The resulting map of Bouguer anomalies (Fig. 3) shows only a very short gravity range of c. $0.7 \mathrm{mGal}$. Due to this fact, the registered anomalies are only of low significance. The most distinct is the band of slightly increased values forming a $\mathrm{W}-\mathrm{E}$ band in the middle of the area and a gravity minimum south of this band.

The density measurements on samples (Tab. 1) revealed surprisingly low density of the basalt sample (2 $757 \mathrm{~kg} / \mathrm{m}^{3}$ with a porosity of $16.45 \%$ ). This value is much lower than the usual $2900-3000 \mathrm{~kg} / \mathrm{m}^{3}$ due to the finely vesicular texture of the sample where the pores only partly communicate. Hence, the traditional method of measuring density and porosity by immersing samples into liquid yields underestimated results. Nevertheless, the measured values imply that the basic dykes and veins saturated (at least partly) with ground water would have the density very close to that of the surrounding sandstones and most likely would not produce a significant gravity anomaly.

The measured magnetic field (Fig. 4) shows three major local anomalies (amplitudes of several hundreds of $\mathrm{nT}$ ) and an area of small-scale local maxima (amplitudes usually lower than $50 \mathrm{nT}$ ) in the centre of the surveyed area. The geometry and structure of magnetic anomalies, namely the shape of negative pole, suggest that the volcanic eruptions most likely took place during the era of reversely oriented magnetic field. The prominent linear anomaly in the north is caused by the microgabbro dyke of roughly W-E direction forming a morphological ridge between the villages of Horní Branná and Valteřice (Fig. 1).

The three maxima in the SW part of the area are most likely associated with the feeder system of the Principálek Volcano. The resistivity cross-section along the profile 5 (Fig. 5) contains a vertical high-resistivity anomaly (more than $150 \Omega \mathrm{m}$ about the x-coordinate $250 \mathrm{~m}$ ) which coincides with the magnetic maxima. Therefore, we interpret this anomaly as a basaltic feederdyke c. $20 \mathrm{~m}$ wide and with its top some $40 \mathrm{~m}$ below the surface (Fig. 9). This dyke is most likely responsible for, at least, two large magnetic maxima in this area. The dyke is roughly parallel to, and situated between, the gravimetric profiles 1 and 4 .

Another prominent feature is the highly inhomogeneous top layer found within the resistivity profile 5 (Fig. 5). This layer is $30-40 \mathrm{~m}$ thick in the central part, located just on the top of the interpreted basaltic dyke. We interpret this as a layer of pyroclastic deposits phreato-magmatic tuffs, phreato-Strombolian and Surtseyan lapilli-tuffs, Surtseyan scoriaceous tuff-breccias, and Hawaiian lava agglutinates (Fig. 9).

The resistivity profile 5 also reveals two low-resistivity slanted anomalies on its edges. The first, located in the SW, begins just beneath the pyroclastic deposit layer (x-coordinates 100-150 m) and is steeply inclined to the NE. The second lies on the NE edge of the profile (xcoordinates $460-500 \mathrm{~m}$ ). However, only its small part is mapped by the profile; we suppose that much of it is out of the surveyed area. A similar anomaly could also be found on the resistivity profile 6 (Fig. 6) at x-coordinates 50-100 m. All of these anomalies are inclined to the area of abrupt changes in the magnetic field and highly heterogeneous resistivities - possible feeder system in the conduit with vent-breccia - and also a small gravity low (Figs 3-6). These facts lead us to interpret these low resistivity anomalies as diatreme breccia facies inclined towards the centre of the diatreme.

The gravity measurements did not provide easily interpretable data. The observed gravity low (Fig. 3, profiles 2 and 4) is insignificant in contrast to usually prominent gravity lows found when surveying young maar-diatreme volcanoes. Nevertheless, it still could represent a mass deficit caused by the maar eruption. Taking into account the expected low density contrast between the poorly consolidated sediments and a diatreme breccia created shortly after the sedimentation finished (see the next section for discussion) we could consider this gravity low to be caused by the diatreme breccia or scoria layers within the diatreme. This hypothesis is also supported by the resistivity profiles showing slanted low resistivity anomalies which are interpreted as diatreme facies and slightly increased 


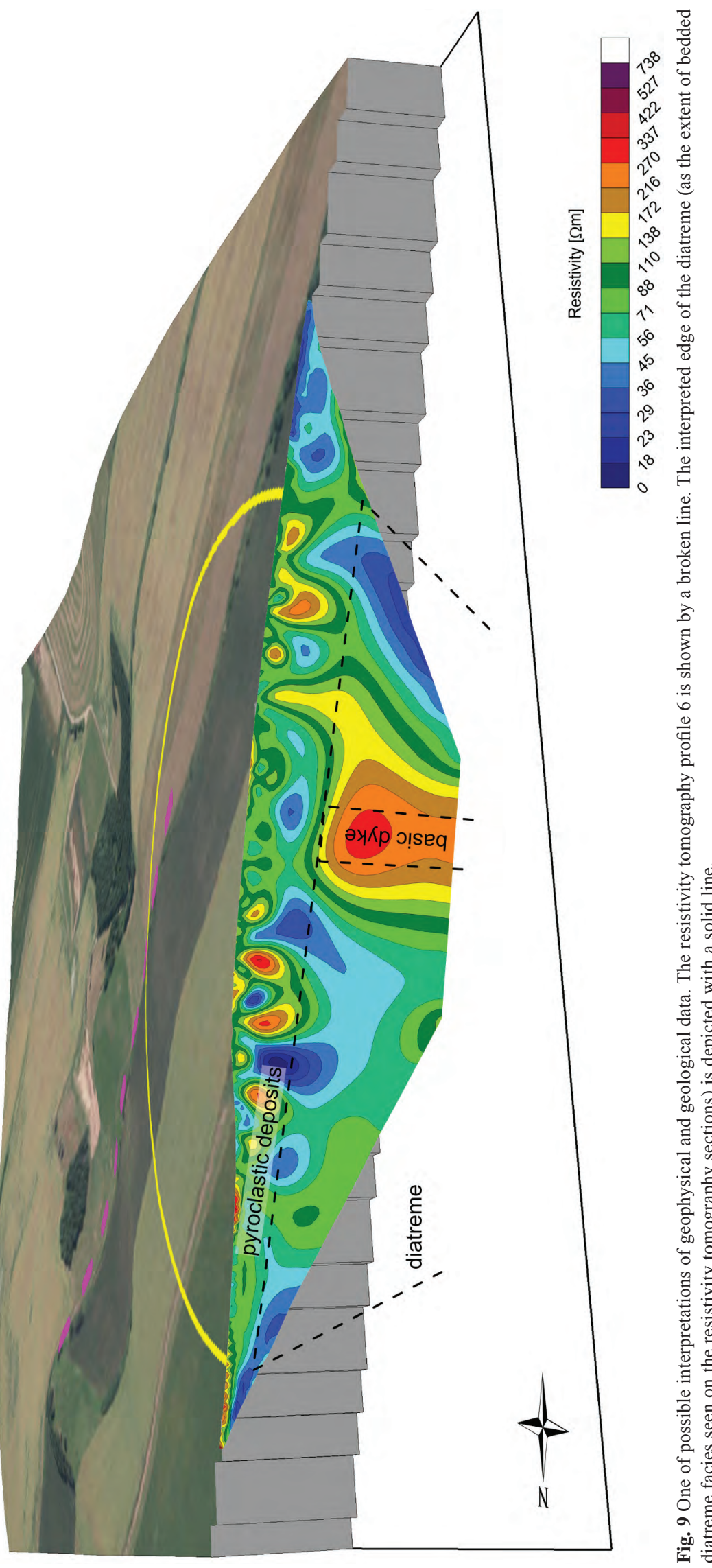

thickness of pyroclastic deposits in the area of gravity low.

The west end of profile 3 (Figs 2-3) shows a local gravity high. With respect to the density measurements (Tab. 1), this could be caused by scoriaceous lava flows found by geological mapping in this area.

\section{Discussion}

The geophysical research of old maar-diatreme volcanoes could be substantially different from studies of Tertiary or Quaternary structures. The gravity method, which is often the workhorse in case of young volcanoes, did not fully fulfil the expectations. The eruption very likely took place soon after sedimentation and, therefore, penetrated poorly compacted heterogeneous and relatively coarse-grained continental sediments. The breccia filling the diatreme shared, until now, a similar burial and compaction history as the country rocks. Hence, there is a little contrast in the gravity field within and around the diatreme as the explosion in such poorly consolidated material likely did not substantially change the density of affected sediments. In other words, the density of loose sediments filling the diatreme did not significantly differ from that of unconsolidated sediments of the country rock and a possible subtle difference remained negligible or even decreased during subsequent diagenesis. Unfortunately, samples of breccia filling the diatreme that would support our hypothesis are inaccessible as no drilling through the Principálek Volcano has been carried out. Thus, our interpretation (Fig. 9) is based more on 


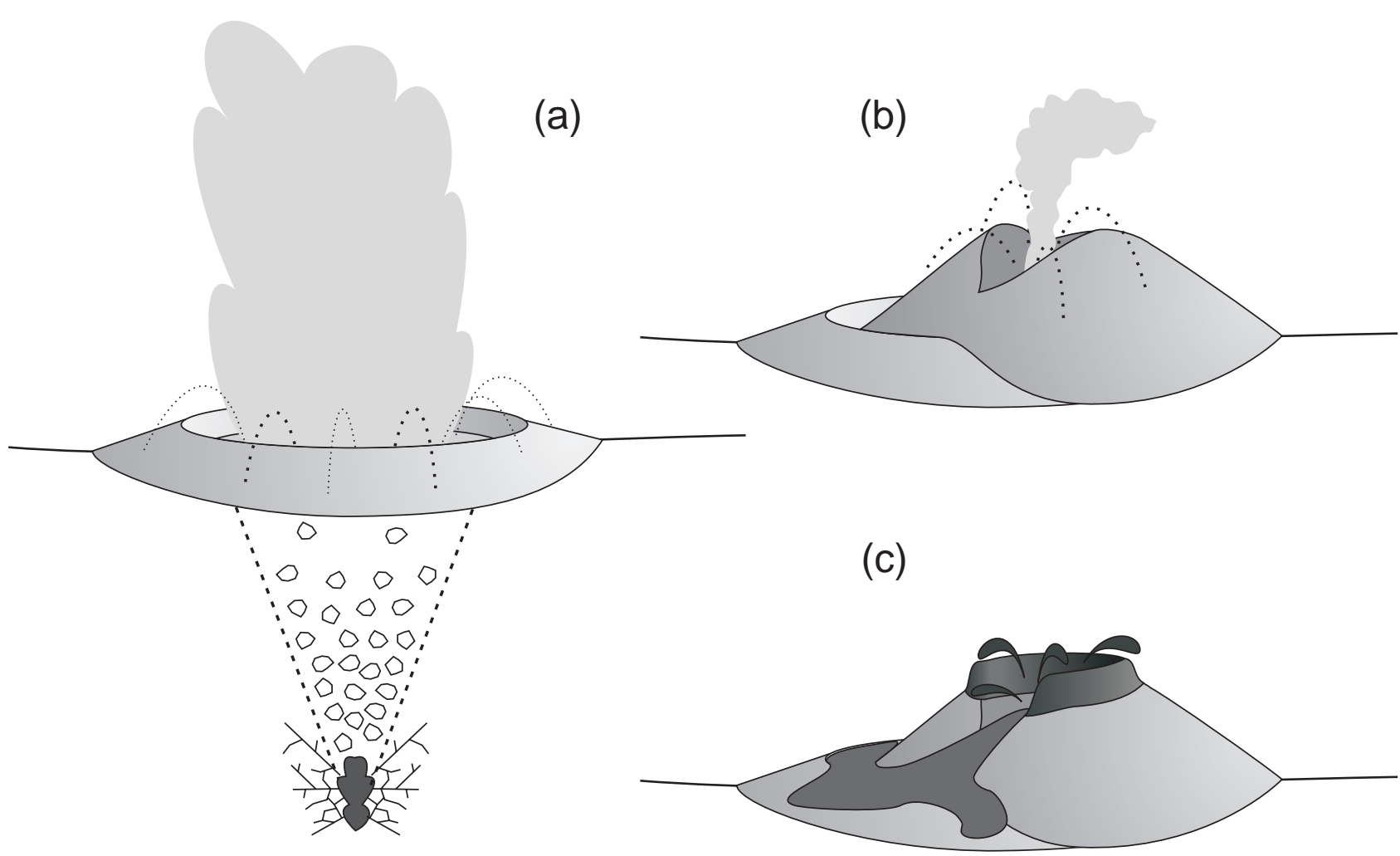

Fig. 10 Tentative evolution of the Principálek Volcano. The magma reaches water-saturated sediments and the volcanism starts with a phreato-magmatic eruption (a). At the second phase, the available water has been already used and the eruption type changes to the Strombolian (b). Finally, the Hawaiian fountain deposits lava and scoria (c).

the DC resistivity method, magnetometry and geological evidence than on the gravimetry. Eruption through the unconsolidated sediments soon after sedimentation and shared burial and diagenetic history set the Principálek Volcano apart most maar-diatreme volcanoes studied world-wide.

The geological evidence could be used to reconstruct the evolution of the volcano (Fig. 10). Several different layers of pyroclastic rocks were found documenting the shift in the type of volcanism:

- The fine-grained tuff with accretion lapilli (Fig. 7b) at the base of the succession is interpreted as a product of phreatomagmatic activity. The occasional cross-bedding suggests the presence of pyroclastic surges.

- The overlying pyroclastic rocks - lapilli tuffs (Fig. 7cd) - are viewed as products of phreato-Strombolian and Surtseyan eruptions on a transition from the early phreato-magmatic activity to the later Strombolian-style eruptions. Alternating layers of variable grain size could reflect changing influence of water on eruption pulses (phreato-Strombolian blasts).

- The overlying coarser pyroclastic succession represented predominantly by scoriaceous tuff breccias (Fig. 7e-g) with spindle-shaped bombs was likely associated with Strombolian activity.
- Finally, the Hawaiian fire fountain deposited shreds of lava and scoria which welded and agglutinated (Fig. 8a).

Based on the magnetic measurements, the later Strombolian to Hawaiian activity concentrated most likely to the SW and NW corners of the surveyed area, where several magnetic highs indicate the presence of basic dykes at depth. The area of supposed diatreme was transected with resistivity profiles 5 and 6 . Profile 6 crossed the diatreme only along the southwesternmost edge; however, profile 5 encountered the whole width of the structure. The resistivity distribution shows inclined layers at the edges of the diatreme (possibly bedded diatreme facies - as also supported by the small gravity low at profiles 2 and 4); the basic dyke in the SW is covered with approximately $30-40 \mathrm{~m}$ of pyroclastic deposits.

The previously mentioned inhomogeneous topmost layer has two zones (x-coordinates $110-160 \mathrm{~m}$ and $310-350 \mathrm{~m}$ ) of an increased resistivity (more than $300 \Omega \mathrm{m}$ ). They could represent areas with high amounts of coarse material less prone to weathering, such as tuff-breccias or agglutinated lava shreds. These zones could indicate two remnants of the scoria and/ or spatter cone(s) from the Strombolian and Hawaiian phases. 


\section{Conclusions}

Geophysical methods have successfully delineated the subsurface structure of a possible maar. In contrast to most of other maar-diatreme volcano studies, the DC resistivity method and magnetometry were proven the most useful. The usually successful gravity method failed here due to the unexpectedly low density contrast between the individual rock types.

The eruption styles of the studied volcano ranged from the phreato-magmatic to the purely magmatic. Geophysical models of the maar structure also correspond well to the interpretations of observed pyroclastic rocks inside the possible maar structure. These comprise deposits of phreato-magmatic eruption at the base, followed by coarse-grained lapilli-tuffs and lapillistones and tuffbreccias with volcanic bombs that document a shift to the Strombolian-style eruption. Finally, lava flows and agglutinates of small spatter cone document the Hawaiian-type eruption in the final phase of the volcano evolution. An important part of the structure related to the diatreme represent basaltic dykes and microgabbro sill intruding sediments and pyroclastics.

The volcano studied developed in several eruptive episodes. The eruption style shifted from the phreatomagmatic via the Surtseyan and Strombolian events to the Hawaiian eruption in the end. Fluctuating magmatic and hydro-magmatic activity was controlled mainly by an aquifer yield, a depth of magma/water interaction, a decrease in water amount available and a drop in magmatic gases contents.

Acknowledgements. This research has been carried out within the framework of Research Plan (AVOZ30460519) of the Institute of Rocks Structure and Mechanics and Strategic Research Plan for 2012-2015 of the Czech Geological Survey (project 321140). Editor-in-chief Vojtěch Janoušek, handling editor Vladislav Babuška, an anonymous reviewer and Horst Kämpf are gratefully acknowledged for their helpful comments. The authors are indebted to Michael S. Petronis for language corrections of the manuscript.

\section{References}

AwdANKIEWICZ M (1999) Volcanism in a late Variscan intramontane trough: the petrology and geochemistry of the Carboniferous and Permian volcanic rocks of the IntraSudetic Basin, SW Poland. Geol Sudetica 32: 83-111

AwdANKIEWICZ M (2007) Late Palaeozoic lamprophyres and associated mafic subvolcanic rocks of the Sudetes (SW Poland): petrology, geochemistry and petrogenesis. Geol Sudetica 39: 11-97
Bolós X, Barde-Cabusson S, Pedrazzi D, Martí J, Casas A, Himi M, Lovera R (2012) Investigation of the inner structure of La Crosa de Sant Dalmai maar (Catalan Volcanic Zone, Spain). J Volcanol Geotherm Res 247-248: 37-48

Cassidy J, France SJ, Locke CA (2007) Gravity and magnetic investigation of maar volcanoes, Auckland volcanic field, New Zealand. J Volcanol Geotherm Res 159: $153-163$

Cunion E (2009) Comparison of ground TEM and VTEM responses over kimberlites in the Kalahari of Botswana. Explor Geophys 40: 308-319

Gebhardt AC, De Batist M, Niessen F, Anselmetti FS, Ariztegui D, Haberzettl T, Kopsch C, Ohlendorf C, ZoLitschKA B (2011) Deciphering lake and maar geometries from seismic refraction and reflection surveys in Laguna Potrok Aike (southern Patagonia, Argentina). J Volcanol Geotherm Res 201: 357-363

Geissler WH, Kämpf H, Skácelová Z, Plomerová J, BABUŠKA V, KIND R (2012) Lithosphere structure of the NE Bohemian Massif (Sudetes) - a teleseismic receiver function study. Tectonophysics 564-565: 12-37

Gernon TM, Upton BGJ, Hincks TK (2013) Eruptive history of an alkali basaltic diatreme from Elie Ness, Fife, Scotland. Bull Volcanol 75: doi: 10.1007/s00445-0130704-7

IBRMAJer J, Suk M (eds) (1989) The Geophysical Image of the ČSSR. Czech Geological Survey and Academia, Prague, pp 31-36 (in Czech)

Kuarsgaard BA, Harvey S, McClintock M, Zonneveld JP, Du Plessis P, McNeil D, Heaman L (2009) Geology of the Orion South kimberlite, Fort a la Corne, Canada. Lithos 12: 600-617

La Terra EF, Menezes PTL (2012) Audiomagnetotelluric $3 \mathrm{D}$ imaging of the Regis kimberlite pipe, Minas Gerais, Brazil. J Appl Geophys 77: 30-38

LOKE MH, BARKER RD (1996), Rapid least-squares inversion of apparent resistivity pseudosections using a quasiNewton method. Geophys Prospect 44: 131-152

Lorenz V (1971) Collapse structures in the Permian of the Saar-Nahe Basin area, southwest Germany. Geol Rundsch 60: 924-948

Macnae J (1995) Applications of geophysics for the detection and exploration of kimberlites and lamproites. J Geochem Explor 53: 213-243

MAtThes H, Kroner C, JAhr T, KÄMPF H (2010) Geophysical modelling of the Ebersbrunn diatreme, western Saxony, Germany. Near Surf Geophys 8: 311-319

Mrlina J, Kämpf H, Kroner C, Mingram J, Stebich M, Brauer A, Geissler WH, Kallmeyer J, Matthes H, Seidl M (2009) Discovery of the first Quaternary maar in the Bohemian Massif, Central Europe, based on combined geophysical and geological surveys. J Volcanol Geotherm Res 182: 97-112 
Nettleton LL (1939) Determination of density for reduction of gravimeter observations. Geophysics 4: 176-183

PešEK J (ed) (2001) Geology and Deposits of Upper Palaeozoic Limnic Basins of the Czech Republic. Czech Geological Survey, Prague, pp 1-243 (in Czech)

Petтit W (2009) Geophysical signatures of some recently discovered large ( $>40$ ha) kimberlite pipes on the Alto Cuilo Concession in Northeastern Angola. Lithos 112: 106-115

Prouza V, Stárková M, Schovánek P, Štor T (2012) Geological map of Czech Republic 1: 25 000, sheet Vrchlabí. Unpublished manuscript, Czech Geological Survey, Prague

Sarma BSP, Verma BK, Satyanarayana SV (1999) Magnetic mapping of Majhgawan diamond pipe of central India. Geophysics 64: 1735-1739

Schmidt A, Nowaczyk N, Kämpf H, Schüller I, Flechsig C, JAHR T (2013) Origin of magnetic anomalies in the large Ebersbrunn diatreme, W Saxony, Germany. Bull Volcanol 75: doi: 10.1007/s00445-013-0766-6
Skácelová Z, Rapprich V, Valenta J, Hartvich F, Šrámek J, Radoñ M, Gaždová R, Nováková L, Kolínský P, PÉCSKAY Z (2010) Geophysical research on structure of partly eroded maar volcanoes: Miocene Hnojnice and Oligocene Rychnov volcanoes (northern Czech Republic). J Geosci 55: 333-345

Stárková M, Rapprich V, Breitkreuz C (2011) Variable eruptive styles in an ancient monogenetic volcanic field: examples from the Permian Levín Volcanic Field (Krkonoše Piedmont Basin, Bohemian Massif). J Geosci 56: $163-180$

Ulrych J, ŠtěPÁnková J, Novák JK, Pivec E, Prouza V (2002) Volcanic activity in Late Variscan Krkonoše Piedmont Basin: petrological and geochemical constraints. Slovak geol Mag 8: 219-234

Vasanthi A, Mallick K (2001) Patterns of occurrence of kimberlite pipes based on gravity and magnetic anomalies in Wajrakarur-Lattavaram region, Andhra Pradesh. J Geol Soc India 58: 251-259 